\title{
Additional Notes on the Structure of Fossil Tree Ferns.*
}

\author{
$\mathrm{By}$
}

\section{Yudzuru Ogura.}

Received Scptember 1, 1941.

The writer described in 1927 two new species of Mesozoic tree fern stems, showing internal structure, under the names of Cyathocaulis naktongensis, gen. et sp. n. and Cibotiocaulis Tateiwai, gen. et sp. n. The former species is determined based on some materials from the Jurassic of South Korea and from the Cretaceous of Wakayama Prefecture, while the latter based on only one incomplete material also from the Jurassic of South Korea. Both of them exhibit the characteristic external features and internal structure, similar to those of the living genera of the Cyatheeae, from which, however, differ in having inwardly curved stelar margins at the leaf gaps and in the presence of medullary root traces. Both species are to be distinguished from each other in the features of petiolar bases.

After described them, the writer is going to consider that the difference of two species is too small to separate them in different genera, and they should be included into a genus, so that the latter species was emended as Cyathocaulis Tateiuai(1938). Recently, the writer studied another fossil tree fern stem, showing structure, from Mindoro, one of the Philippine Islands. This is very similar to the above described Japanese species, but is distinguished by the presence of a few cortical meristeles. This difference has no generic value, so that this was described as Cyathocaulis Yabei, sp. n. (1941).

The cortical meristeles of the Philippine species are so small in size and so few in number that they may be overlooked. It was true that the writer recognized, in the preparations of Japanese species, a few small bundle-like tissues in the cortex, whose preservation was, however, too bad to define their true nature, and he did not touch on such a structure.

In spring of 1940, the writer had an opportunity to visit Korea and to collect numerous specimens of fossil tree ferns, at the places where the original specimens were collected, in order to do further studies which were missed in the former investigation. After making some preparations,

* Contributions from the Divisions of Plant Morphology and of Geneties, Botanical Institute, Faculty of Science, Tokyo Imperial University, No. 280. 
the presence of cortical meristeles was made clear in both species, so that it is desirable to add this fact and some others to the former informations in 1927.

\section{Cyathocaulis naktongensis, OGura.}

Cyathocautis nalitongensis, OGur.1. Journ. Far. Sei. Tokyo Inp. Unir. Sect. III. Vol. 1, p. 352, 1927.

Materials from Korea.

Original specimens were collected by Dr. I. Tateiwa from N. Kü̈ngsang Dô of Korea, of which four specimens were sent to the writer ( Nos. $2 \mathrm{~A}, 2 \mathrm{~B}, 2 \mathrm{C} \& 2 \mathrm{D})$. In the preparations from them doubtful tissues of cortical meristeles were observable only in one or two. Near the placess where the TATEIwA's specimens were collected, the writer could find numerous fragments of fossil tree ferns and brought back about fifty specimems

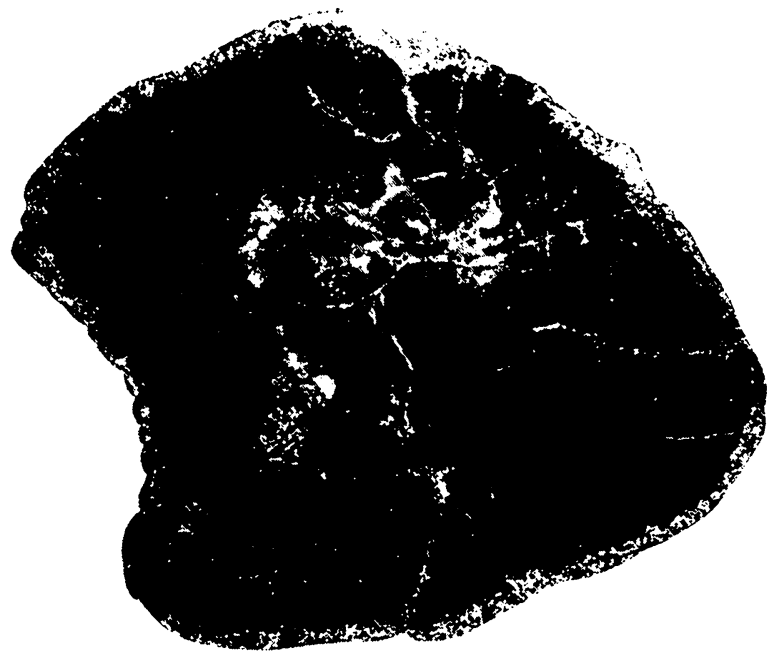

Fig. 1. Cyathocauils naktongensis, no. 57. Polished root mass; vascular system of the stem well visible. $\times \frac{1}{2}$. cross surface, showing the stem surrounded with thick

(Nos. 2, 3, 4, 9, 10, 12, $13,14,15,16,17,18,19$, $20,21,22,23,2 \overline{5}, 26,27$. 28, 29, 30, 31, 32, 33, 34 . 3.5, 36, 37, 38, 39, 40, 41 . $43,44,45,46,47,48,49$. $50,51,52,54,55,56 \&$ $5.7)$. Some of them are nearly round, but mostly more or less flattened. Most of them are thick, as their stems are surrounded by their own thick root cluster; the stem is about $8-10 \mathrm{~cm}$. in diameter, while the whole diameter measures 10-20 cm. or more (Fig. 1). One of the largest specimens (No. 43) measures $60 \mathrm{~cm}$. in length and $30 \mathrm{~cm}$. in thickness. Most of them are preserved somewhat better than the TATEIwA's specimens, and some new observations could be made.

The Cortical Meristele. The structure of the main stele and medullarymeristeles surrounded by their own sclerenchymatous tissues, the mode of departure of leaf traces, the presence of cortical as well as medullary root traces are just as given in the former information, and there are no necessity to give further demonstrations (Fig. 2). It should be noticed here 
only the presence of cortical meristeles, which were failed to find in the former study. They are few in number and small in size, so that they cannot be observed in the polished surface, and to observe them the large preparations through the whole part of the stem should be made.

Among the preparations newly made, one (No. 57) contains only two cortical meristeles in the whole cortex, while in other preparations, in which a part of the cortex is damaged, four (No. 54), three (No. 21), two (Nos. $56 \& 46$ ), one (No. 26) or no (Nos. $15 \&$ 38 ) cortical meristeles are found, though there are some other doubtful tissues at the corresponding places. Comparing these preparations, it may be

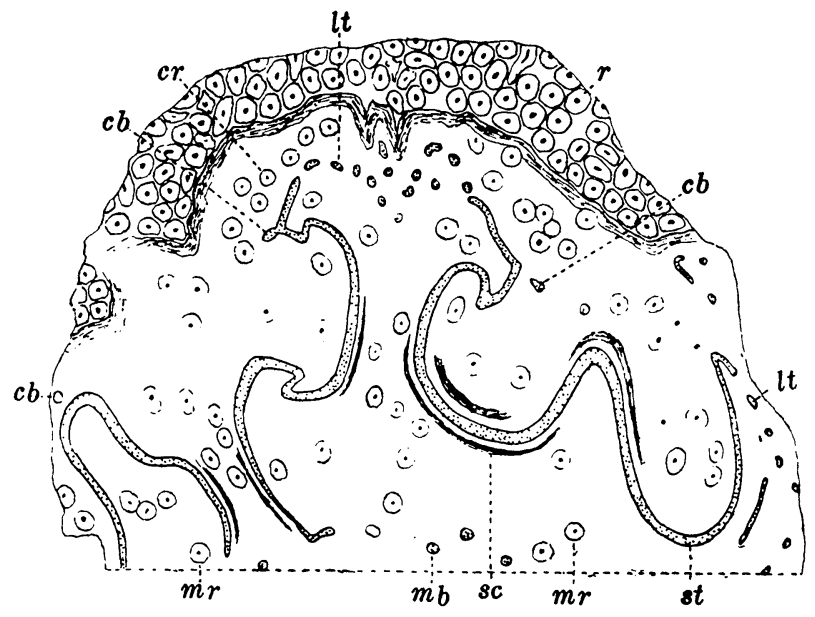

Fig. 2. Cyathocaulis naktongensis, no. 54. A part of the preparation, showing general structure; some of the tissues ill preserved. $\times 2$.

$r$, root; st, stele; sc, sclerenchymatous sheath; $l t$, leaf trace; $c r$, cortical root trace; $m r$, medullary root trace; $m b$, medullary meristele; $c b$, cortical meristele. concluded that they are few, at most five or six in a cross section, so that in the incomplete preparations the cases without them may be met with. That the writer missed their presence in the former study is based on this fact. As their number is few, the course of the cortical meristeles may be

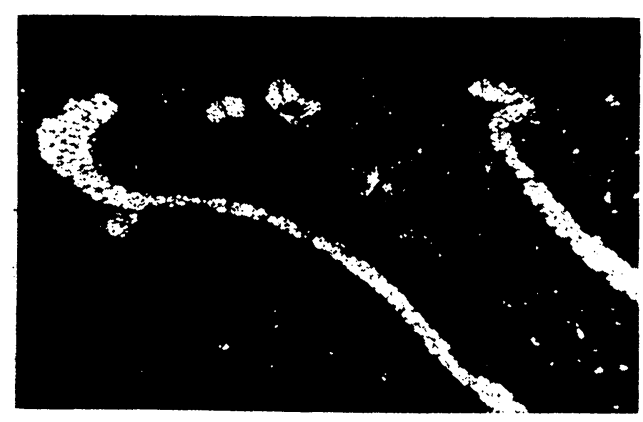

Fig. 3. Cyathocaulis naktongensis, no. 56 . A part of the preparation near an outgoing leaf trace, showing a cortical meristele on the left. $\times 8$. assumed. They appear in pair as small protuberances of the stelar ring, when it bulges out as for a leaf trace, and after separating from it they ascend along the leaf trace and finally fuse there (Fig. 3). Their course is therefore rather short and is similar to that of some living Cyatheacean species, and when the leaf traces overlap with each others, some pairs may be found in one cross section. 
The cortical meristele is small, much smaller than the medullary meristele, and consists of mass of some small tracheids. It is situated near the main stele, mostly interrupting the sclerenchymatous sheath of the latter. It is therefore distinguishable from the root traces, which are situated outside the sclerenchymatous sheath and consist of a small bundle surrounded by a broad cortical tissue.

Additional Notes. In most cases the stem is surrounded by thick root masses, and in some preparations (Nos. 15, $21 \& 56$ ) hairy structure is found on the stem surface, protected by the roots. It consists of filiform, uniseriate, multicellular hairs, arranged closely together, just as those of living species of Dicksonieae (Fig. 4). This point is important, because the stelar system is rather similar to that of the living Cyatheeae, whose stem is, however, surrounded by scaly hairs, while the filiform type is similar to that of the Dicksonieae.

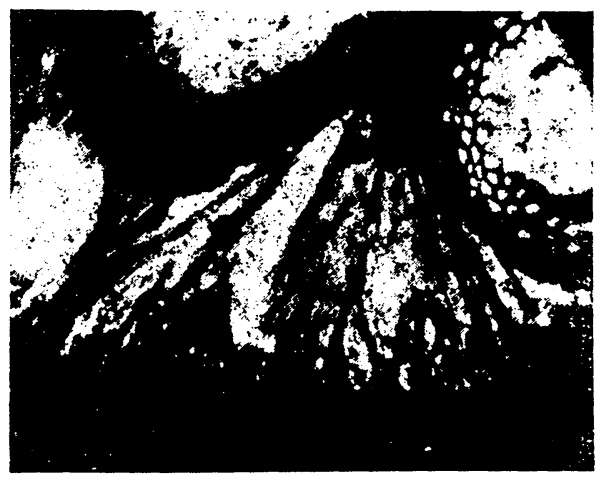

Fig. 4. Cyathocaulis naktongensis, no. 21. A part of the periphery of the stem, showing a cluster of filiform hairs. $\times 40$.

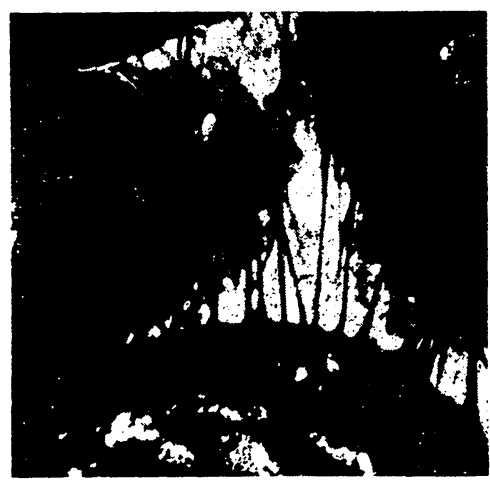

Fig. 5. Cyathocaulis naktongensis, no. 21. A part of the root mass, showing the root hairs. $\times 40$

Hairy structure is also found on the periphery of some roots in the root mass. It consists of long unicellular hairs, representing, with no doubt, the root hairs (Fig. 5). They are thinner than the stem hairs.

Another peculiar structure is found among the root mass. It is similar to the root in form and size, but differs in having an arc-formed tracheidal band in its center. Some of such tissues are found among the root mass; they represent the bundles of the petiole, whose fundamental tissue is mostly decayed away and is replaced by root mass, just as we meet with in many living ferns (Fig. 6).

Materials from Wakayama-Prefecture.

To obtain further materials, the writer visited in 1941 the place where he formerly (1926) collected some specimens, but it was in vain, as the 


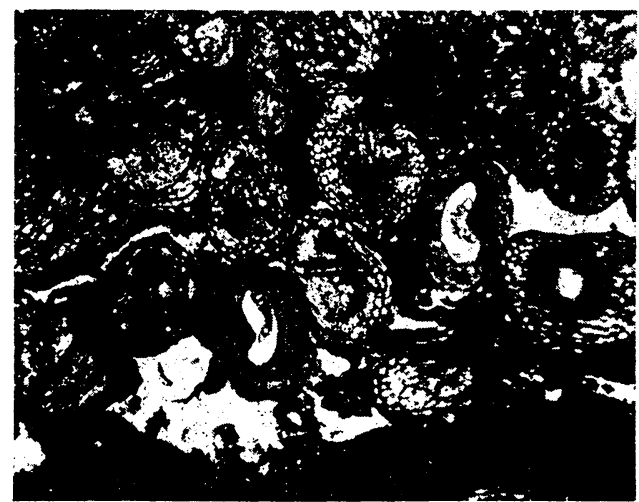

Fig. 6. Cyathocaulis naktongensis, no. 56. A part of the root mass, showing the intermingled remains of petiolar bundles, each with an areshaped tracheidal band. $\times 10$.

place changed to a fruit garden, so that some additional preparations were newly made from the original specimens. Comparing them with original preparations, the writer could confirm the presence of the cortical meristeles (Nos. C, D \& I). In most incomplete preparations none of them is observable, and even in larger one they count only one or two. Their size, structure and course are, however, the same with those of Korean specimens (Fig. 7).

Though the materials from Wakayama are somewhat smaller than those from Korea, their internal structure is quite the same with that of the latter. The structure of the medullary meristele and its own sclerenchymatous sheath, which is one of the characters useful for specific distinetion, is also identical in both materials.

\section{Cyathocaulis Tateiwai, OGura, emend.}

Cibotiocaulis Tateiwai, Ofura. Journ. Fac. Sci. Imp. Univ. Tokyo. Sect. III, Vol. 1, p. 346, 1927.

Cyathocaulis Tateiwai, Ogura. Anatomie d. Vegetationsorgane d. Pteridophyten. Handl). d. Pfanzenanat. 2. Aht. 7. p. 353, 1938; Jubl. Publ. Prof. YABE, Vol. 2, p. 918, 1941.

In the former study, the genus Cibotiocaulis was established based on one incomplete specimen from N. Kyöng-sang Dô of Korea. Studying this specimen, the writer separated this from the former genus, Cyathocaulis, in that, (1) the petiolar bases remain on the stem surface and (2) the leaf traces show the arrangement of Cibotium type. Afterwards, he considers that the difference of both species is too small and they should belong to 
a single genus, so that he emended this as Cyathocaulis Tateiwai (1938). This conclusion was ascertained from the study of newly collected materials. Materials from Korea.

Near the place where the TAterwa's specimen (No. 5) was collected, the writer could find numerous fragments of fossil ferns, and some of them were brought back (Nos. 62, 63, 64, 65, 66, 67, 68, 69, 70, 71, 72, 73, 74, $75,76,77,78,79,80,81 \& 86)$. This place is not so far from that where the former species is found (about $6 \mathrm{~km}$. apart). They are much smaller

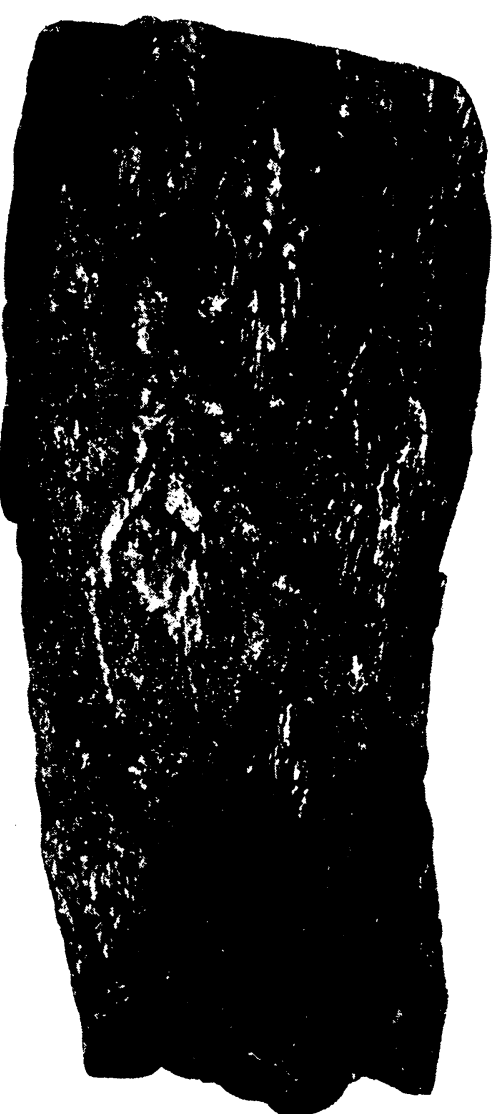

Fig. 8. Cyathocaulis Tatciwai, no. 64. Stem surface, showing remains of petiolar bases with some vascular bundles. $\times \frac{1}{2}$. living Cyatheeae. That the writer came to the different result in the former study was based on the incompleteness of the material.

The Cortical Meristele. Another point of new investigation is the recognization of cortical meristeles, which were missed in the former study. 
The mode of their appearance is quite similar to that of the former species; they are few in number, four in a complete cross section (No.63), and in incomplete preparations, four (No.71), three (No.66), two (Nos.67 \& 78) or none (No. 76) of them are found. Their size, form and course are quite similar to those of the former species (Fig. 9). so that their detailed description will be omitted here.

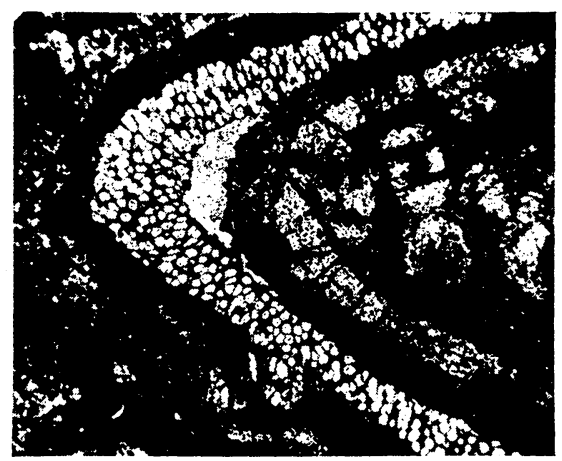

Fig. 9. Cyathocaulis Tateiwai, no. 66. A part of the preparation near an out. going leaf trace, showing a cortical meristele on the lower side. $\times 8$.

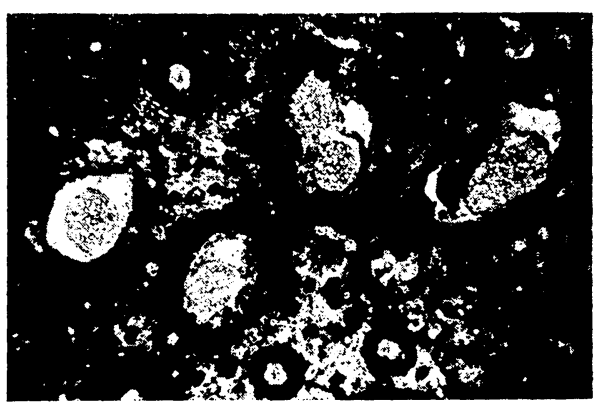

Fig. 10. Cyathocaulis Tateiwai, no. 76. A part of the pith, showing the medullary meristeles surrounded ly selerenchymatous sheathes. $\times 8$.

Additional Notes. In the former study, the presence or absence of sclerenchymatous sheath round the medullary meristele could not be determined owing to bad preservation. In the new materials we can see its presence nearly in all of the medullary meristeles. This tissue surrounds each meristele more or less completely or is interrupted in one or two places (Fig. 10). This is one of the different points from the former species, in which the sclerenchymatous sheath is largely separated or scarcely developed, though in some larger meristeles the sheath sorrounds them more or less completely.

The presence of filiform hairs on the outer surface of the stem, which was described in the former information, is also newly confirmed (No. 78). Their structure is.similar to the former species. As formerly described, filiform hairs are present in the stems of Dicksonieae among the living Cyatheaceae, while in those of Cyatheeae scaly hairs are characterized. On these facts, the writer considered this species having an affinity with Dicksonieae rather than Cyatheeae, and gave the name ribotiocaulis. This conclusion is ought to be eorrected, because it is now confirmed that such hairy structure is also found in the former species. Both speries are thus to be included in one genus.

In some roots round the stem are found hairy structure, incompletely 
preserved, which may represent the ront hairs, just as cleseribed in the former species.

\section{Conclusion.}

1. In cyathocullis nuliongensis there are few cortical meristeles, which appear accompanying with the outgoing leaf traces. They are few and small. The presence of filiform hairs on the stem surface is also confirmed.

2. In Cibotiocaulis Tuteiwai, most of the anatomical characters are identical with the former species; the presence of a few cortical meristeles and filiform hairs on the stem surface is also the same, so that this species is very similar to the former one, and rather may be included in the former genus, being thus emended as Cyathocaulis Tateiwai.

3. Cyathocaulis Tateiwai inay be distinguished from C. natitongensis (1) in the petiole bases, which remain somewhat elevated in this species. while in the latter they fall off from their very bases, (2) in the root mass round the stem, which is rather poor in this species, while in the latter strongly developed, and (3) in the sclerenchmatous sheath of the medullary meristeles, which is rather "omplete in this species rather than in the latter.

4. Cyathocaulis Yabei from the Philippine Islands is another. but related species, showing also a few cortical meristeles. The distinction of these species lies in the structure of medullary meristeles and their sclerenchymatous sheathes:-

C. Yabei: medullary meristele mity contain small pith; selerenchymatous sheath absent.

C. naktongensis: medullary meristele rontains no pith; sclerenchymatous sheath absent or present, if present, interrupted mostly.

C. Tateiuai: medullary meristele contains no pith; sclerenchymatous sheath more or less complete.

5. In the living Cyathecae, the medullary meristeles are always present, but the cortical ones are either present or absent; even among the species of the same genus one has them but another has not. Their presence or absence has not, therefore, the generic character. This may be also applied to the fossil Cyatheaceae, and it may be reasonable that in the genus ryathocautis both forms, with or without them, may be included.

\section{Literatures.}

OGura, Y. 1927. On the structure and affinities of some fossil tree-ferns from Jilpan. Journ. Fac. Sci. Imp. Univ. Toḳno. Sect. III. Tol. 1, Pt. 3. 
Oglas, Y. 1938. Anatomie der Vegetationsorgane der J'teridophyten. Handb. d. Pflanzenanat. 2. Abt. 7.

- 1941. On the structure of a fossil tree fern stem from Mindoro, Philippine Islands. Jubl. Puhl. Prof. YABE, Vol. 2.

\title{
化石木生羊齿ノ構造二關スル追補（和交摘乫；
}

\author{
小會橦
}

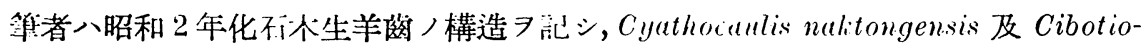
caulis Tateiwai）二新屬新種 7 發表七リ(東大理紀要・植物・1卷)。共二朝魝度份北 道ノ座ニシテ, 前者八唒ホ和歌山縣二モ座ス。丽種卜モ現今ノ八ご科二類スル大ナル

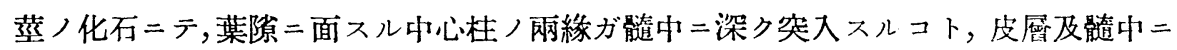
根跡ノ存在スルコトナドニ於テ現今，へど科卜區別ヒンル。而シテ二屬ノ相異、葉 柄ガ前者ニテハ基部ヨリ離落スルニ反シ, 後者ニテハソノ基部ヨ殘贸スル點ニアリ。

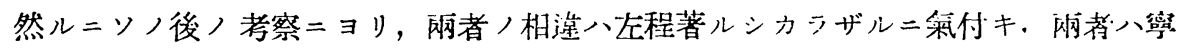

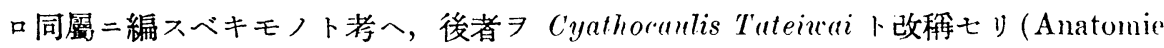
d. Vegetationsorgane d. Pteridophyten. 1938)。

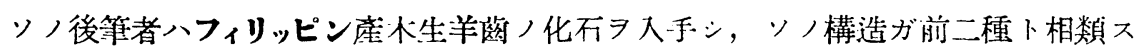

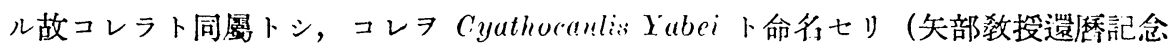
論交集, 2 卷. 昭和 16 年)。コノ種ノ特徵ハ少數ナガラ皮脣中二維管束佟ノ存在スル コトナリ。前二種ニハカ、ル皮走維管束條ヨ認メザリシガ, ソレラシキ組織ノ存在:

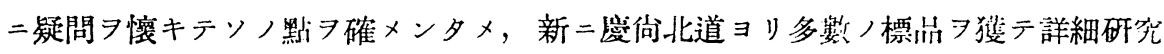
ノ結果，前二種ニモりノ存在ヨ碓認スルニ至レリ。但シイヅレモ少數ニシテー・横斷 面二數倜ヨ算スルニ過ギズ。

份ホ二種卜モ䔲/表面二毛/存在习認メシガ，ソノ毛八鱗毛ニアラズシテ多細胞 ヨリ成ル絲狀ノモノナリ。コレ現今ノたかわらび族（Dicksoniea(）二見ラル、型ナ

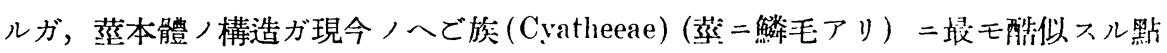
ト一致セザル所トス。

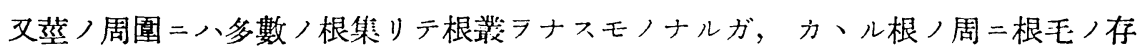
在ヨ認メタリ:

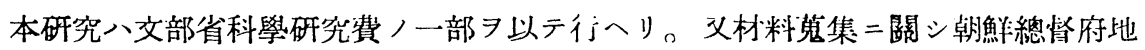

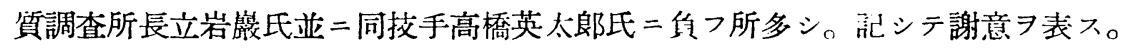

